\title{
The Implication of the Village Act on Women Representation in Villages as a Realization of Sustainable Democracy: A Study In Semarang Regency's Villages
}

\author{
Ani Purwati ${ }^{1}$, Budi Ispriyarso ${ }^{1}$, Dyah Wijaningsih ${ }^{1}$ \\ \{ani_purwanti81@yahoo.com ${ }^{1}$ \} \\ Universitas Diponegoro ${ }^{1}$
}

\begin{abstract}
The enactment of the Village Act (Law No.6/2014) conveys a new vigor to democratization on the village level. Through village democratization, the village can develop and prosper as a self-governing community to which every villager is equally able and entitled to participate and voice their opinions in the decision-making process for the sake of the village's betterment. Yet in fact, noting that women in Indonesia still experience hindrances and deliberate obstacles that oppress them from voicing their opinions. Hence, the Village Act tries to resolve such by mandating women representation in the village decisionmaking body, the Village Representative Council. This article aims to explore the implication of the Village Act on women representation in villages. The analysis of which is based on preliminary research was executed in Semarang Regency's villages. The fact we found is that since the enactment of the Village Act, the villages of Semarang Regency have undergone significant progress whereby women representation is escalating statistically and promoted vehemently throughout by various social elements. After all, we contend that the Village Act acts as a proposition for the inclusion of women in village politics through which the consequent actions can be conveyed as a collective initiative that will invigorate women villagers to contribute more in the decision-making process.
\end{abstract}

Keywords: Women Representation, Village Democratization, Village DecisionMaking, Village Act

\section{Introduction}

There are around 73.000 villages in Indonesia that make up the lowest level of government in the national administration system which starts by the state to the provincial, district, subdistrict, and then village, respectively. Moreover, the inception of decentralization which has been established since 2001 contributes to a far-reaching impact to Indonesia's administrative system whereby governmental power, which was once solely controlled by the state government, starts to be distributed respectively to lower governments on designated degrees. This is known as "regional autonomy" whereby local governments are given authority by the state to govern its own territory extensively. The regional autonomy also affects local governments of the village-level, the extent of which is the freedom for the village to selfgovern, thus ending its subjugation of authority from the higher administrative [1], [2]. In 
regard to village autonomy, this matter has been advocated vehemently by village activists as to the freedom of village to self-develop and to retain their cultural traditions and identity. This is due to the impact of modernization and extensive capitalism of the New Order era which were solely centered on urban cities whereas the villages were left underdeveloped, mostly below the poverty line [2]-[4].

In respect to which, decentralization in Indonesia is brought forward as a part of the democratization process. Since the Reformation era, the Indonesian government has been committed to reform its institutions -especially administrative institutions- to be democratic through the signing of Sustainable Development Goals [5] a global-wide pact of the commitment of the state parties to realize the stipulated goals. As to democracy, participation and representation of all societal elements in democratic institutions of decision-making must be taken into account in order to achieve sustainable democracy, a democracy that could withstand a matter of crisis. Therefore, the exclusion of those who are rightful to be involved in the democratic process would only lead to a negative turn which degrades the efforts of democratic transition and social consolidation for cooperativeness and peace.

Gender equality is one of the main goals in Sustainable Development Goals which is essential for the advancement of democratization [5], [6]. Indonesia government has responded the issue of gender equality by establishing gender quota in legislative candidacy and political party membership through the Political Party Act (Law No.2/2011) and the Legislative Election Act -recently amended in the Law No. 7/2017). The quota system is considered as breakthrough and innovative in terms of gender equality advancement in Indonesia as the lack of women participation in politics has always been a critical issue [7], [8]. Following the popularity of quota system, the growing issues of decentralization and democratization of village have also brought up the issue for women representation as well which then manifested through the enactment of the Village Act (the Law No. 6/2014 on Village). In the village act, there is a provision which mandates women representation in the membership of Village Representative Council, the legislative body of village, albeit without gender quota system. However, the absence of gender quota system suggests a creative method of political inclusion towards women through which particular factors of the village's background may be taken into account, thus the objective of this article. This article analyzes such problem in Semarang Regency's villages whereby the Village Act has implemented vehemently and thoroughly including on the issue of women representation in Village Representative Council.

\section{Method}

The type of research in this article is socio-legal research. Socio-legal research is used due to the needs to see the implication of law or regulation to the empirical context of social life [4]. This article will be focused on the implementation of two local regulations of Semarang Regency; the Regency Government Regulation No. 4/2018 and Regent Decree No. 21/2018. The analysis of which will then be compared to empirical data as to the law's implementation on the site. Such empirical data that will be presented are primarily quantitative (statistical data).

\section{Result and Discussion}

\subsection{Women Representation in Semarang Regency's villages after the Village Act}


The enactment of Village Act was applauded as a breakthrough policy nowadays due to its fundamental objectives of promoting inclusivity and development for villages which were once underdeveloped and marginalized due to centralized modernization. Another provision which promotes inclusivity for marginalized community is women villagers which are often overlooked in the bigger scope of women movement agenda in Indonesia [9]. Article 58 paragraph (1) of the Village Act, it is stipulated that, "the number of members of the Village Representative Council is set in odd numbers, five to the last and nine maximum, under considerations of territory, women, population, and financial capability of Village." Although the Act does not elaborate further on that provision regarding women representation, it is clear that given the certainty of the law, women must be included within the membership of Village Representative Council. Instead, women representation is elaborated further in derivative regulations that are Government Regulation No. 43/2014 and Ministerial Regulation of Home Affairs No. 110/2014 in which mandates strictly for a minimum one woman representative in any established Council. Yet, these regulations do not shed a light further on how women representative should be elected, how her position is representative enough for women interests, and how women representative can be kept in check by her ought-to-be constituency that is women.

The government of Semarang Regency takes up the action on resolving those unanswered questions left by the Village Act -and its derivative regulations-. As of 2018, the Semarang Regency government has enacted two legislations regarding Village Representative Council in which women representation is stipulated; the Regent Government Regulation of Semarang No. 4/2018 and the Regent Decree No. 21/2018. The regulations stipulate the mechanism of women representation as such followings:

1) The filing of women representation into Village Representative Council is only allowed for one seat per Council;

2) A rightful candidate of women representative shall be a qualified female villager who have been proven to be experienced as an advocate of women rights, the burden of proof of which shall be based on the recognition of constituencies (women rights activists and women groups).

3) The election of said women representative shall be based on the voting of female villagers who have a right to vote or registered at local electoral commission.

Although the regulations only require one women representative per Council, it does not mean that the system is misogynistic. "Women representative" here is understood as a representative who is elected directly by and for designated constituencies which consist of local women leaders, activists, women groups, and women villagers in general. This "women representative" is a result of affirmative action in order to ensure representation of women interests in the decision-making process of village. Nonetheless, a Council can have more than one female members yet the other females do not necessarily entitled as "women representative". Instead, a female candidate can be elected by popular vote regardless of gender-based interests.

As of the enactment of the Regent Government Regulation of Semarang No. 4/2018 and the Regent Decree No. 21/2018, there is a drastic influx of women representatives into Village Representative Councils in Semarang Regency. Semarang Regency consists of 19 sub-districts in which there are 208 villages and 27 kelurahan. The 2017 census reported that each village in Semarang Regency has a Village Representative Council, thus there are 208 Councils in total. The statistical data on the Council's memberships in total is described in tables below: 

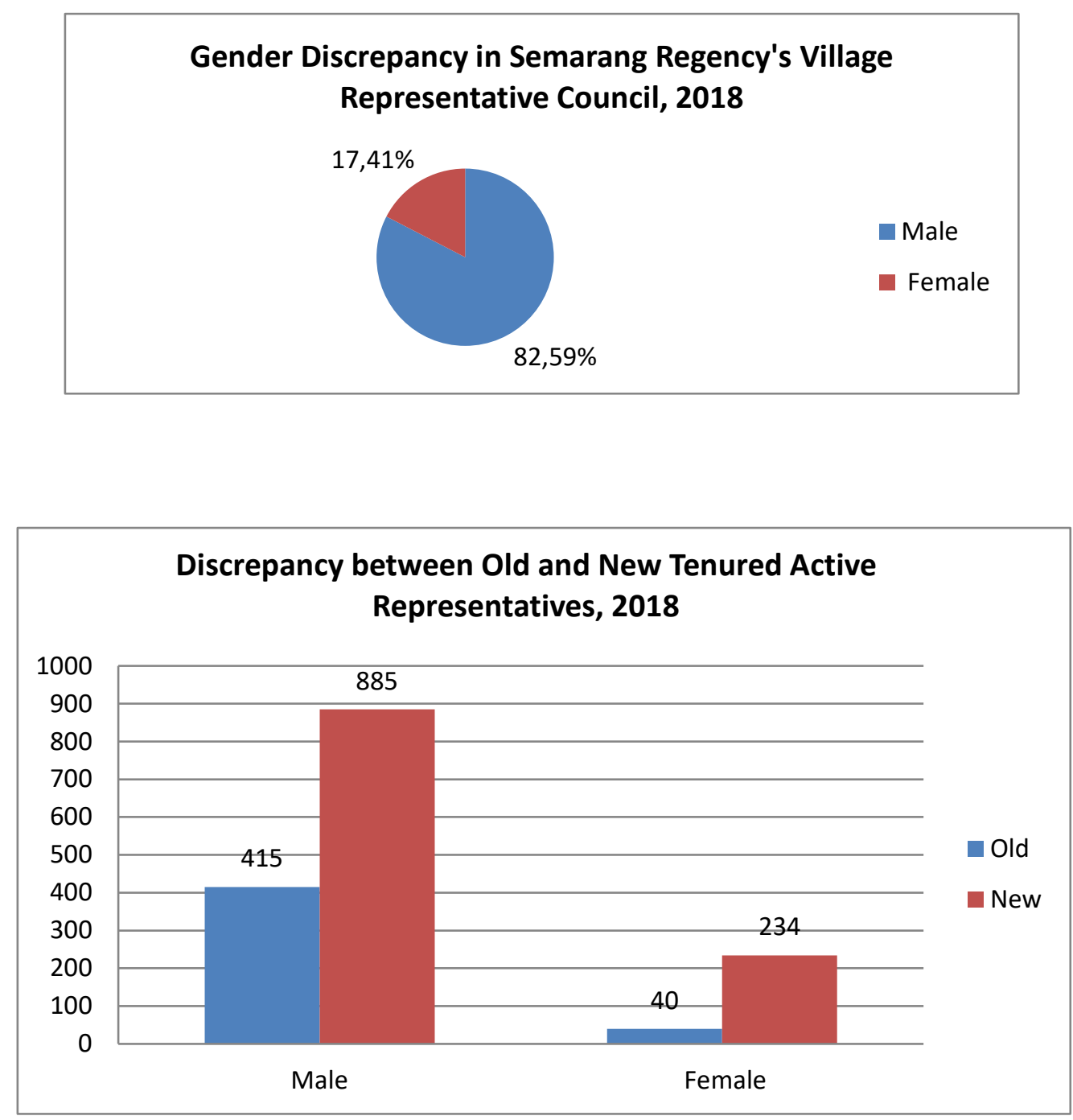

Source: Village Empowerment Agency, Semarang Regency Government, 2018

As shown in the table, there are two discrepancies in the memberships of Village Representative Councils in Semarang Regency. First is, obviously, gender discrepancy whereby the male members are more dominating the seats in the Councils. Whereas the second discrepancy is tenure. Our research reported that 52 Village Representative Councils are still having old-tenured members, 24 of which do not have any women representation. Whereas the rest of 156 Councils have had undergone new election and are now having women representation for at least 1 member in each Council. These discrepancy criteria are intertwined as a reciprocal effect whereby the male-female ratio of the new-tenured Councils are better inasmuch as 3.78:1 respectively whereas the old-tenured Councils only have 10.375:1 male-female ratio respectively.

Moreover, the gender-tenure discrepancy in Semarang Regency's villages indicates the aftereffect of full implementation of the Village Act in Semarang Regency through the enactment of the Regent Government Regulation of Semarang No. 4/2018 and the Regent Decree No. 21/2018. The data are the result of deliberate action from the Semarang Regency Government. It is said that the electoral periods between villages are different due to internal 
considerations within the village. Apparently, the enactment of the Regent Government Regulation of Semarang No. 4/2018 and the Regent Decree No. 21/2018 were hastened in respect to the incoming village election. The result is an escalating influx of women participation in politics as women, collectively or individually, were started competing in election as either the village head or village representative, thus making women politics to be trendy and common in Semarang Regency. The statistical data show its positive outcome.

\subsection{Representativeness of Women Representative in Village: Progress and Challenges}

It is, indeed, that political inclusion of marginalized and minority groups into democracy is an important perquisite of a democracy to be sustainable and worth preserving. An inclusive democracy will open up an aspiration canal for those groups through which their opinions and interests can be taken into the account of decision-making process which the outcome is expected to be positive to the represented groups. However, it is hard to simply believe that a mere presence of women within the decision-making process will lead to a proliferation of gender mainstreaming policy or a realization of gender-sensitive social institution. Mandated representation -quota system- is applauded as a quick option of actualizing women representation in legislative body, yet it is often, if not always, be criticized for the potential of reducing representation into merely numbers without any intention of advocating the represented's interests to the deliberation table, a representation in quantity yet without quality [7], [10]-[15].

As aforesaid, democratization process is a process of institutional reform through which the rules that support the system are changed in a way by which the institutional system is able to accommodate political rights and provide equal opportunity for all people to be involved in decision-making process on matters relating to their lives [16]-[18]. Sustainable democracy needs a realization of inclusivity based on not only quantitative benchmarks, but also qualitative to which matters of representativeness are taken into account. Representativeness means indicators of a representative is capable and accountable enough to represent and advocate the issues and interests of people they represented [19], [20]. Other said that representation based on visible similarities between the representation and the represented i.e. women should be represented by women only- is a reliable factor for the citizens to feel represented enough, namely symbolic representation [14], [15], [19], [21]. Whereas on the other side contends that representativeness factor must be relied on substantive aspect as the extent to which the representative is passionate and vehement enough in action as to voicing and advocating the interests and opinions of people they represented, thus namely substantive representation [11], [19], [22]-[24]. Based on these two indicators, we can shed a light on how representative the women representation system in Semarang Regency's villages is.

Throughout observations on the regulatory system and its implementation on women representation in Semarang Regency, it is contended that the system as outlined in the Regent Government Regulation of Semarang No. 4/2018 and the Regent Decree No. 21/2018 exhibits a substantive representation. The regulations mandate a minimum one seat -numerical quotaspecifically for female representatives as a reservation of seat for women's opinions and interests to be present. However, the regulations also provide two mechanisms that ensure the accountability and representativeness of the woman representative in Village Representative Council which are through: constituent delegation and Village Deliberative Forum. In the Regent Government Regulation of Semarang No. 4/2018 and the Regent Decree No. 21/2018, the process of delegating a female candidate to be a woman representative must be conducted, deliberated, and executed by women constituents in which women social figures, activists, 
women groups, or women villagers in general can participate and deliberate on delegating their candidate. What expressed here is that the process of direct delegation by women constituents denote the role of women representative as an agent instead of aspirational leader of the movement. Moreover, the accountability mechanism also exists after the election as through Village Deliberative Forum, a periodical meeting in which the village government usually represented by the Village Head-, Village Representative Council, and community elements can deliberate and give suggestion to the governmental process of the village. Through this forum, the accountability of both the village government and Village Representative Forum can be kept in check as the community elements are rightful to ask. Regarding women representation, the Regent Government Regulation of Semarang No. 4/2018 and the Regent Decree No. 21/2018 stipulate that community elements also include women constituents as the third party in the Forum. Therefore, the forum becomes a formal momentum whereby women constituents and women representative can reciprocally deliberate, keep each other checked, and advocate together on pushing women empowerment agenda into the policy table. Moreover, the Regent Government Regulation of Semarang No. 4/2018 and the Regent Decree No. 21/2018 also stipulate the obligations for the representatives to develop their capacity and intensify their communication with the constituent as such corresponding agenda can be included in the funding proposal of village budget.

Yet, challenges remain as whether or not the implementation of substantive representation will work positively to the advancement of women welfare in village. There are several concerns that emerge throughout the research. First is quantity; it is hard to be convinced that one reserved seat for women representation is considerably enough to represent and advocate women interests while she is facing other 4 to 8 men in the Council, regardless of how representative she is to the constituent. Second, males are still relatively dominating in villages' leadership, this matter can hinder the progression of gender equality advocacy as which tends to subjugate the bargaining position of women representative and women activism in village in deliberative process. Third, the lack of capacity-building on gendermainstreaming. However, this matter might depend on external influences in which women rights movements can be involved in the political process of women representation in Semarang Regency's villages. However, there is no reported data about its occurrence yet.

\section{Conclusion}

In respond to the trend of decentralization and democratization of local government, thus village, as mandated by the Village Act and SDGs, the issue of gender equality and women political participation also expand to the context of village. The government of Semarang Regency has responded so by establishing the Regent Government Regulation of Semarang No. 4/2018 and the Regent Decree No. 21/2018, two regulations in which women political participation is established and ensured in village decision-making process. The statistical data have shown a substantial improvement as to women representation in Village Representative Council as all newly tenured Village Representative Councils have one female representative to the least. Assessing from the mechanism and purposes stipulate by the Regent Government Regulation of Semarang No. 4/2018 and the Regent Decree No. 21/2018, it is concluded that these two regulations have an exhaustive mechanism to ensure women political representation in both quantity and quality. The two regulations adopt the living customary tradition of deliberative social politics and modern democracy governance which impacts to the guarantee of accountability and representativity of women representative on putting women interests 
forward to the policy-making. Therefore, the women political representation provisions within the Regent Government Regulation of Semarang No. 4/2018 and the Regent Decree No. $21 / 2018$ indicate a purposive establishment of political system that is inclusive and sensitive to women issues which are substantial to the development of gender equality and gender justice in the social life of women in village.

\section{References}

[1] A. Bebbington, L. Dharmawan, E. Fahmi, and S. Guggenheim, "Local capacity, village governance, and the political economy of rural development in Indonesia jj," World Dev., vol. 34, no. 11, pp. 1958-1976, 2006.

[2] J. A. C. Vel and A. W. Bedner, "Decentralisation and village governance in Indonesia: The return to the nagari and the 2014 Village law," J. Leg. Plur. Unoff. Law, vol. 47, no. 3, pp. 493-507, 2015.

[3] H. Antlöv, "Village government and rural development in Indonesia: The new democratic framework," Bulletin of Indonesian Economic Studies, vol. 39, no. 2, pp. 193-214, 2003.

[4] H. Antlöv, A. Wetterberg, and L. Dharmawan, "Village Governance, Community Life, and the 2014 Village Law in Indonesia," Bulletin of Indonesian Economic Studies, vol. 52, no. 2, pp. 161-183, 2016.

[5] L. Joy, M. H. Wagne, and S. Narayanan, "Report: The Bottom Line: Corporate Performance and Women's Representation on Boards," catalyst, 2017. .

[6] F. Mackay, “THICK' CONCEPTIONS OF SUBSTANTIVE REPRESENTATION: WOMEN, GENDER AND POLITICAL INSTITUTIONS," Representation. 2008.

[7] A. Purwanti, "Quota Law' S for Women in Politics : Implementation in Indonesia," South East Asia J. Contemp. Business, Econ. Law, vol. 6, no. 4, pp. 28-36, 2015.

[8] W. Z. B. Siregar, "Parliamentary representation of women in Indonesia: The struggle for a quota," Asian J. Women's Stud., vol. 11, no. 3, pp. 36-72, 2005.

[9] B. A. Olken, "Direct democracy and local public goods: Evidence from a field experiment in Indonesia," Am. Polit. Sci. Rev., vol. 104, no. 2, pp. 243-267, 2010.

[10] E. Bjarnegård and P. Zetterberg, "Why Are Representational Guarantees Adopted for Women and Minorities? Comparing Constituency Formation and Electoral Quota Design Within Countries," Representation, vol. 50, no. 3, pp. 307-320, 2014.

[11] K. Celis, "Representativity in times of diversity: The political representation of women," Women's Stud. Int. Forum, vol. 41, pp. 179-186, 2013.

[12] A. Clayton, "Women's Political Engagement Under Quota-Mandated Female Representation: Evidence From a Randomized Policy Experiment," Comp. Polit. Stud., vol. 48, 2015.

[13] D. Dahlerup, "ELECTORAL GENDER QUOTAS: BETWEEN EQUALITY OF OPPORTUNITY AND EQUALITY OF RESULT," Representation, 2007.

[14] D. Dahlerup, "Women, quotas and politics," Women, Quotas Polit., 2013.

[15] D. Dahlerup and L. Freidenvall, "Quotas as a 'fast track' to equal representation for women," Int. Fem. J. Polit., 2005.

[16] S. Besson, "Human rights and democracy in a global context: Decoupling and recoupling," Ethics Glob. Polit., vol. 4, no. 1, pp. 19-50, 2011.

[17] J. Cohen, "Procedure and Substance in Deliberative Democracy," Democracy and Difference: Contesting Boundaries of the Political. 1996.

[18] W. R. Potapchuk, "Building sustainable community politics: Synergizing 
participatory, institutional, and representative democracy," Natl. Civ. Rev., vol. 85, no. 3, pp. 54-59, 1996.

[19] H. C. M. Jr. and H. F. Pitkin, "The Concept of Representation,” Polit. Sci. Q., 1969.

[20] J. Maggio, “Can the Subaltern Be Heard?': Political Theory, Translation, Representation, and Gayatri Chakravorty Spivak," Altern. Glob. Local, Polit., vol. 32, no. 4, pp. 419-443, 2007.

[21] K. Bird, "The Political Representation of Women and Ethnic Minorities in Established Democracies: A Framework for Comparative Research. Academy for Migration Studies in Denmark, Aalborg, 32." 2003.

[22] J. Mansbridge, "Should Blacks Represent Blacks and Women Represent Women? A Contingent 'Yes.,"” J. Polit., 1999.

[23] J. Parkinson, "Deliberating in the Real World. Deliberating in the Real World: Problems of Legitimacy in Deliberative Democracy," 2006.

[24] L. Wängnerud, "Women in Parliaments: Descriptive and Substantive Representation," SSRN, 2010. 